\title{
Rethinking biases
}

Een meerstemmig gesprek over postkoloniale blinde vlekken in cinema

Liesje Baltussen en Steff Nellis

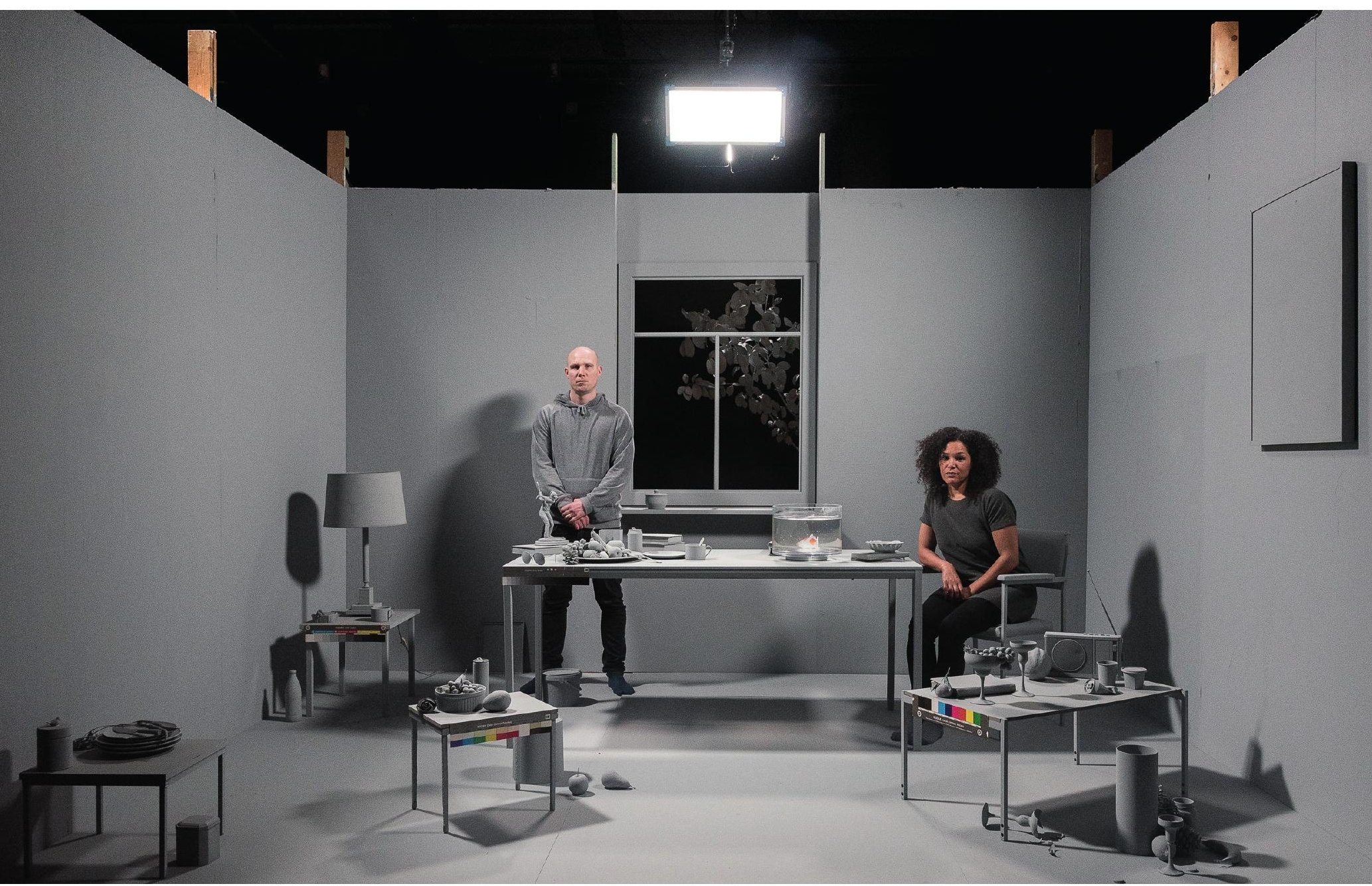


Waarom is het tegenwoordig nog moeilijk om twee lichamen met verschillende huidskleur samen vast te leggen? Waarom ervaren zwarte performers zoveel problemen met make-up en lichtinval op filmsets? Hoe is het mogelijk dat projecten van filmmakers zonder strikt Belgische achtergrond vaak maar moeilijk financiële steun genieten? Het zijn enkele van de blinde vlekken in het filmmaken die PRISM (2020) blootlegt. Drie filmmaaksters met een verschillende huidskleur, An van. Dienderen, Rosine Mbakam en Eléonore Yameogo, werken samen met producent Natalie Gielen rond het 'dekoloniseren van de cinematografie'. Hun filmproject, $P R I S M$, is een cocreatief gesamtkunstwerk dat uitgaat van het idee dat het filmisch medium de witte huid op technologisch en ideologisch vlak bevoordeelt ten opzichte van donkere huidtypes. Ze lichtten dit project toe op The Big Conversation on Alternatives (2019). Hier ontmoetten zij Liesje Baltussen en Steff Nellis. Die werkten in hun opleiding Theater en Film bij dramaturg Kristof van Baarle ook met het thema 'decolonizing the gaze' en zij besloten over PRISM in gesprek te gaan met de filmmaaksters. Helaas bleken de agenda's moeilijk verenigbaar en kon alleen initiator An van. Dienderen zich vrijmaken voor een interview. Daarom deconstrueren

STEFF NELLIS: Via deze link kan u bijdragen aan het open document door opmerkingen en wijzigingen toe te voegen. Liesje Baltussen en Steff Nellis in dit artikel naar voorbeeld van het team achter PRISM het klassieke format van het interview of essay. Onderstaand artikel is immers veel meer dan een weergave van het gesprek met An van. Dienderen. Ook de overige partijen, Rosine Mbakam, Eléonore Yameogo en Natalie Gielen, deelden hun reacties en bedenkingen. Zo ontstond een collectief werkdocument waarin iedereen zijn of haar mening kon delen. En het gaat nog verder dan dat: we heten ook $u$, de lezer, van harte welkom om deel uit te maken van onze conversatie aan de hand van een open Google Drive-bestand. Door ons werk open te stellen, hopen we talloze reacties te verzamelen, opdat het leerproces omtrent 'decolonizing the gaze' hier niet eindigt.

LIESJE: Laten we onszelf even voorstellen. Naast onze raakpunten, focus ik persoonlijk meer op documentaire cinema, daarbinnen dan vooral de avant-garde kant. Daarom vind ik projecten als Lili (2015) en PRISM erg interessant.

STEFF: Ik ben vooral bezig met theater. Momenteel onderzoek ik een nieuwe tendens in het theaterlandschap: de rechtbank in een theatraal format. Hoe worden rechtszaak-performances georganiseerd?

AN: Ik denk dan aan Chokri Ben Chika en De Waarheidscommissie. En Zuid-Afrika, ook.

STEFF: Ja, de Truth and Reconciliation Commissions. Mijn onderzoek draait vooral om de speling tussen wanneer iets een theatraal tribunaal is, of wanneer het rechtszaken zijn die veel van theater weghebben. Dus eigenlijk het verschil tussen de show-trials en trial-shows. Die speling is heel interessant, want er is ook veel overlap.

\section{AN: Zijn er nog recente stukken die dat gebruiken?}

STEFF: Milo Rau bijvoorbeeld, met The Congo Tribunal (2017), de Zurich Trials (2013) en de Moscow Trials (2013). Op Theater Aan Zee was er ook het Proces tegen de Dood (2018) en Christophe Meierhans maakte Trials of Money (2018). En er was ook Crime and Punishment (2017) van Peter Aers.

\section{ROSINE MBAKAM: A ce} point $\mathrm{ci}$, je sens ce sentiment complexe que j'étais quand j'arrivais en Europe pour étudier le cinéma. J'étais confronté avec des références culturelles et intellectuelles que je ne comprenais pas et ça m'a mis à distance. Je sens cette distance à nouveau au le début de cet entretien, mais je le sens moins à la fin.

\section{原} STEFF: Rosine heeft hier zeker een punt. Wie zijn wij om onze eigen interesses hier opnieuw centraal te stellen? Het was onze intentie om een gesprek tussen gelijkwaardige partners op te stellen zodat het klassieke format van een interview onderuit werd gehaald. We stonden er echter niet bij stil dat deze praktijk eveneens in name dropping zou kunnen vervallen of op zijn minst zo zou kunnen overkomen. Rosines opmerking over 'decolonizing the gaze' is dan ook zeer welkom.
LIESJE

BALTUSSEN:

https://vimeo.com/ 136103027

http://www.anvand
8I. LIESJE: Inderdaad! Onze bedoeling was duidelijk om de eigen positie te thematiseren, maar in plaats van vooral onze privileges duidelijk te maken zijn we misschien te veel gaan focussen op projecten die ons interesseren, waardoor we inderdaad in het name dropping zijn vervallen. Ik ben dan ook dankbaar voor Rosine's opmerking, die ons hierop wijst.
STEFF: Voor meer info over deze voorstellingen, zie volgende links:

http://www.the-

congo-

tribunal.com/ http://internation al-

institute.de/en/th e-zurich-trials/ http://internation al-

institute.de/en/th e-moscow-trials/ https://www.yout ube.com/watch? $\mathrm{v}=\mathrm{fbmR7} \mathrm{gMikTU}$ https://www.kaai heater.be/nl/age nda/trials-of-

money

https://stamgent. be/nl be/evene menten/gesprekperformancecrime-andpunishment21maa 
STEFF: Maar laten we het nu hebben over de inzet van dit gesprek. Omdat Eléonore, Rosine en Natalie er vandaag niet bij kunnen zijn, is het de bedoeling dat het resultaat een soort experimenteel document wordt waarop iedereen - Rosine, Eléonore, Natalie en jijzelf An - nadien nog kan inwerken. Op die manier kan iedereen bijdragen aan het gesprek.

LIESJE: Het mag erg rommelig worden. Jullie mogen We denken aan dingen doorstrepen, bijschrijven, toevoegen, weghalen. Dat hoeft niet binnen de grenzen van de taal te blijven: als iemand ergens beeld of audio bij zou willen, mag kan die persoon zich vrij voelen om dat er gewoon bij te zetten. Alles kan! We kiezen hiervoor omdat we graag jullie idee rondom PRISM willen doortrekken in ons werk. Zoals jij, An, bij PRISM Rosine en Eléonore wil laten inwerken op jouw beelden, zo willen we hun ook nu vrij spel geven om in te werken op wat voortkomt uit dit interview met jou.

NATALIE GIELEN: ik denk dat het meer is dan inwerken op beelden. Dat was oorspronkelijk de bedoeling, maar we hebben nu geprobeerd om de samenwerking nog meer open te trekken en samen rond één thema (het belichten van verschillende huidskleuren) te werken binnen één film.

AN: Laat ik mezelf dan ook even voorstellen. Ik ben een documentaire filmmaakster, maar ik heb ook een achtergrond in vergelijkende cultuurwetenschappen. Ik heb daarom altijd geprobeerd om praktijk en theorie met elkaar te verweven door praktijk te maken en theorie daaruit te laten ontstaan. Zo kom ik tot reflectie over processen. Praktijk is sinds ik doctoreerde, en nu nog steeds, mijn ingang tot reflectie, tot theorie. Ik vind dat je vanuit die practice-based research een aantal perspectieven kan ontwikkelen die je niet alleen kan ontwikkelen op basis van theorie. Dat is zo'n beetje de 'hoe'. En 'wat' ik doe: ik ben vooral geïnteresseerd in het onderzoeken van hoe formats ideologische lagen of betekenissen incorporeren die op zich weinig zichtbaar zijn. Dat is een algemene noemer die ik in verschillende projecten al gevolgd heb. In die noemer komen inzichten uit verschillende velden samen: antropologie, feminisme, dekolonisatie, cultuurwetenschappen, film, documentairefilm etc.

STEFF: Het is enorm interessant dat Natalie deze vraag stelt. Onze positie is immers geprivilegieerd: wij zijn twee witte mensen die de kans kregen om aan de universiteit te studeren en onderzoek te verrichten naar postkolonialisme. Aan die universiteit kregen we echter bepaalde denkkaders aangereikt die we als objectief beschouwden, terwijl deze allerminst objectief en eerder gegrond zijn in een westers discours. De vraag is terecht: wie zijn wij om onszelf voor te stellen? Wie zijn wij om onze praktijk in deze context te willen kaderen? Het is dezelfde kritiek die we lazen in Rosines reactie...
KRISTOF VAN BAARLE: Dit is taalgebruik dat impliciet een hiërarchie insinueert. Je zou dit kunnen aanpassen, maar deze dan wel openlijk laten staan.

LIESJE: Ik bedacht me bij het
aanpassen dat we al snel
vervielen in het wegwerken van
pijnlijke/hiërarchische
uitdrukkingen door ze simpelweg
te ontwijken. Het feit dat we maar
moeilijk een alternatieve
uitdrukking vonden die toch nog
de zinsstructuur kon bewaren,
toont misschien dat de fout niet in
de gekozen woorden ligt maar
toch nog in een grotere structuur
van denken.

NATALIE: fijn dat jullie jezelf voorstellen in het begin. Maar wie zijn jullie binnen de context van een werkwijze die poogt te dekoloniseren? Wat zijn jullie privileges? Jullie denkkader?

\section{EIESJE: Inderdaad!}

STEFF: Door jouw artikel rondom Lili, An, werden we ons bewust van het feit dat achter elk format bepaalde normen schuilgaan:

If one wants to question ideological notions in film, then this also means tackling the norms embedded in formats. Mainstream documentary images are conceived in a conventional way, and therefore help to maintain a certain balance of power (2017).

Zo zijn wij ook beginnen na te denken: wat schuilt er in het format van artikelen die wij traditioneel schrijven? We denken dan aan de objectieve houding die we moeten aannemen, de manier waarop je jezelf uit je eigen tekst moet schrijven, dat het geheel één uitgelijnde nette tekst moet zijn met één bron per statement. Dat zijn enkele dingen die we onderuit willen halen door het anders te doen. Dat is ook iets dat in jullie symposium van The School of Speculative Documentary terugkwam: durven te twijfelen, durven onzekerheden te tonen.

An: Ik heb daarover ook nog een andere tekst geschreven. Een artikel over het werk van Roy Villevoye

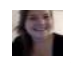
LIESJE: https://vim eo.com $/ 32$ 6350555 en Jan Dietvorst waarin ik de term messiness binnen documentaire introduceer.

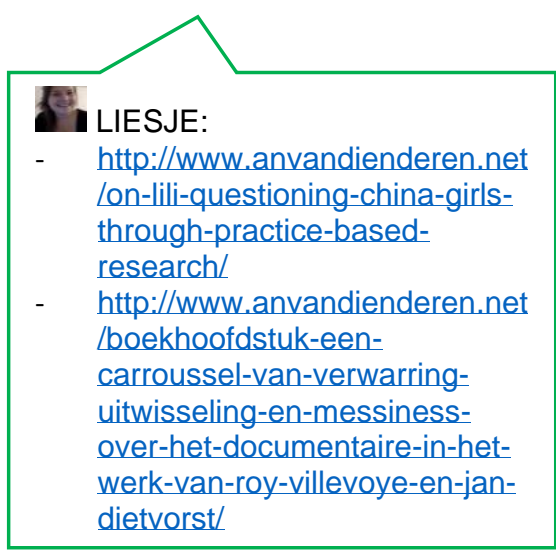




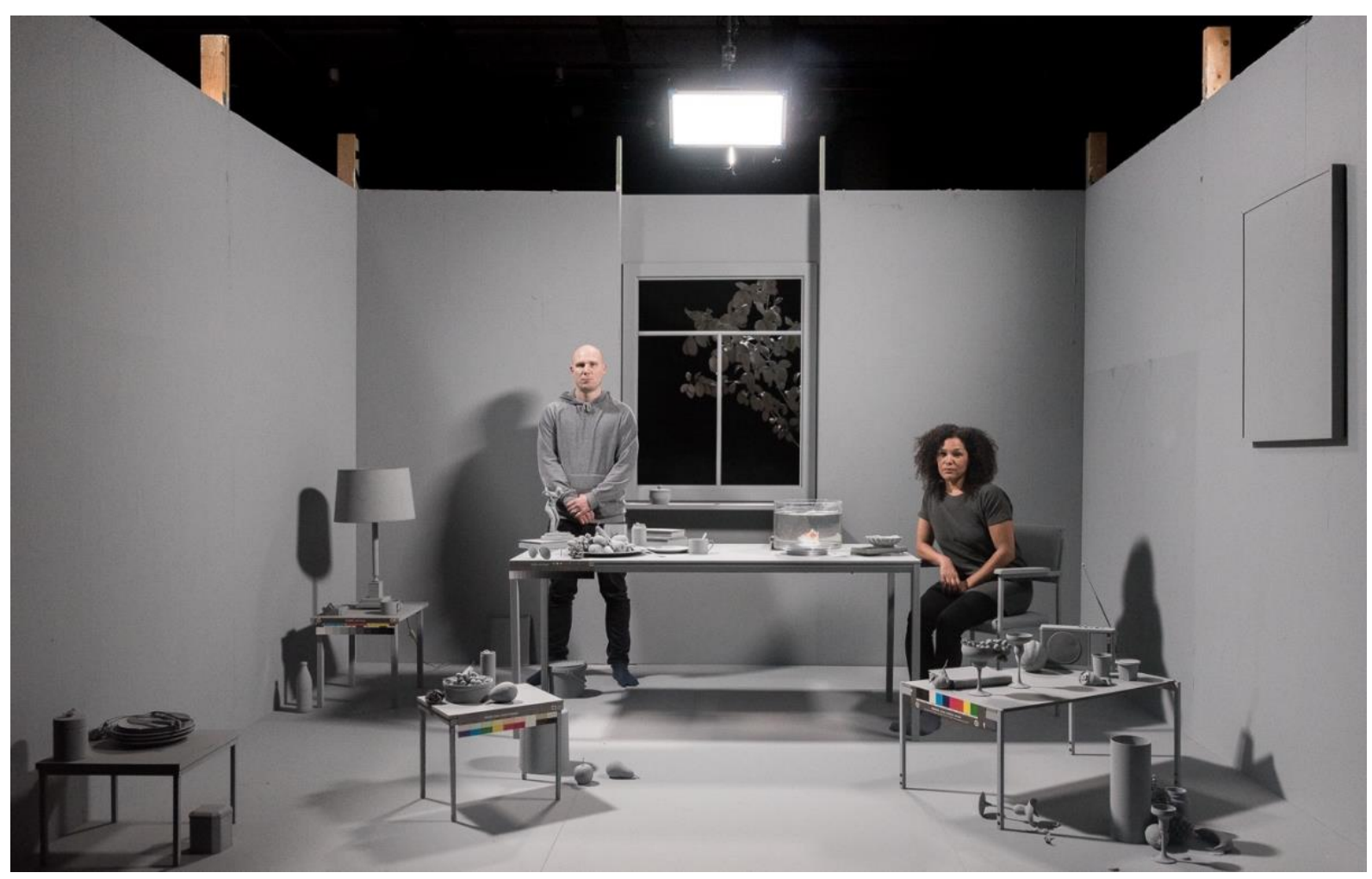

PRISM - An van Dienderen ( $)$ Thomas Nolf 


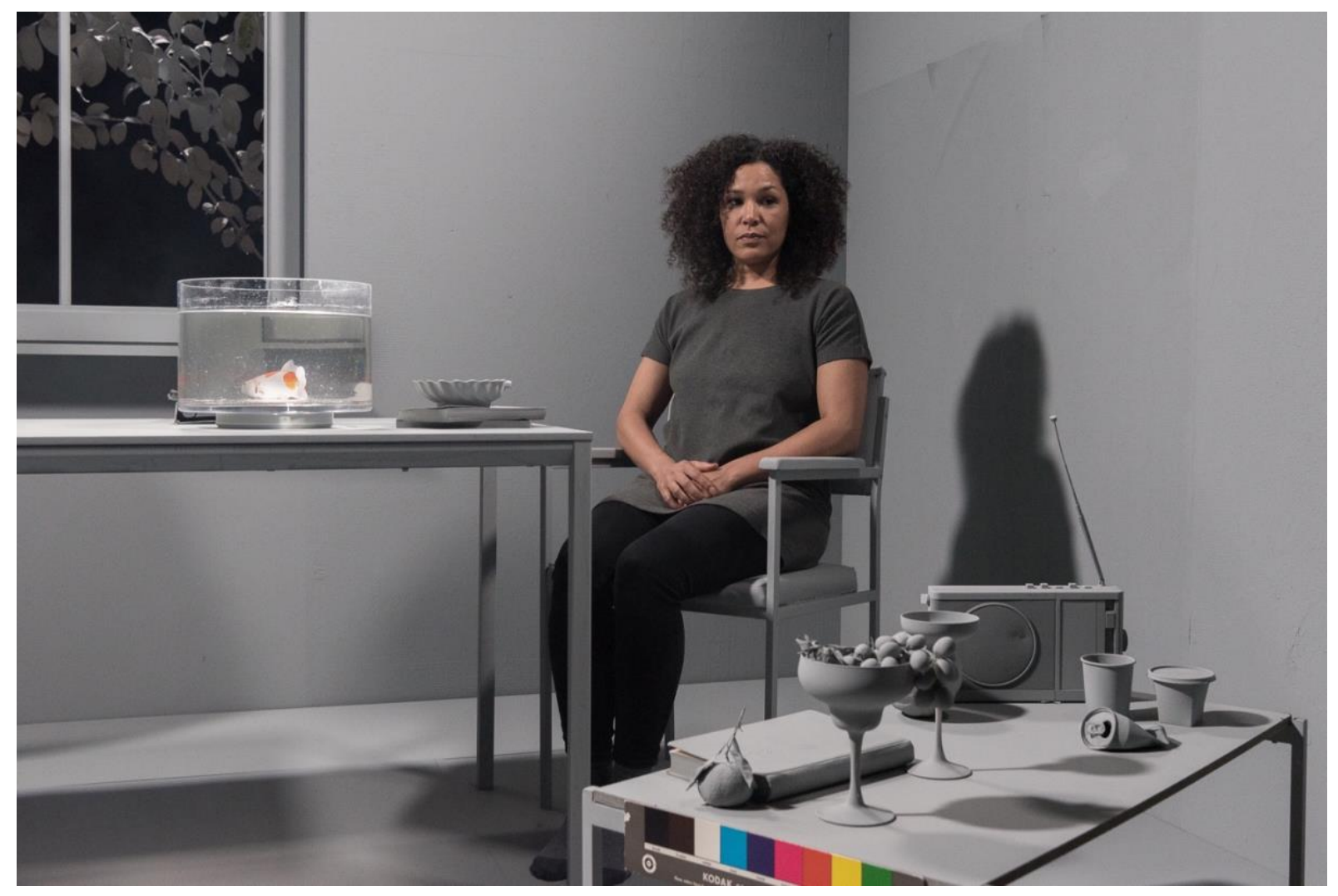

PRISM - An van Dienderen $@$ C Thomas Nolf 
An: Inderdaad. Dat klinkt een beetje onnozel, maar messiness is voor mij de meest productieve documentaire methode, een methode die aangeeft hoe complex de relaties zijn tussen het Westen en zijn geconstrueerde anderen. Die complexiteit wordt in veel documentaires gereduceerd tot een heel eenvoudig, dichotomisch 'wij' tegen 'zij'. Met de School of Speculative Documentary zijn we daar echt tegen. We willen die complexiteit proberen weer te geven en de relaties tussen de maker en het onderwerp openlijk tonen. Maar tegelijkertijd is messiness ook een esthetische categorie natuurlijk, waar je je doorstrepingen en je probeersels, falen en onzekerheden ook opneemt in je werk. Dat sluit helemaal aan bij wat jullie hier ook doen.

LIESJE: Ja, zo'n methode komt voor ons ook dichter bij de realiteit dan dat we dit gesprek in een format of kader zouden proppen waar het niet in past. We merken dat messiness een methode is die men vandaag de dag steeds meer durft aan te nemen. We wilden het daarnaast ook met jou hebben over de methode Speaking Nearby, een concept van Trinh Minh-ha.

AN: Ja, ik ben heel schatplichtig aan haar werk. Ik zag haar films voor het eerst in het STUK toen ik zelf nog film studeerde en ik was echt van mijn sokken geblazen. Ik was tegelijkertijd ook erg verontwaardigd en ambetant, een hele mix van emoties. Maar ik wist dat ik iets had ervaren dat ik nog nooit eerder ervaren had. Ik heb enkele jaren met haar samengewerkt in UC Berkeley. Uiteindelijk ben ik daar twee jaar verbleven en heb ik met haar gewerkt. Onze levens zijn nog altijd wel een beetje verweven en het is altijd fijn om haar en haar werk terug te zien. Zij incorporeert voor mij de bron van hoe je intersectioneel kan kijken. Ze deed dat al voor die term daadwerkelijk gelanceerd was, vanuit haar eigen praktijk, en dat is voor mij altijd een bron van inspiratie geweest.
ROSINE: Je me retrouve un peu dans cet expression messiness. Après mes études de cinéma, j'ai essayé de me libérer de ce que j'avais appris pour trouver une forme singulière qui me caractérise et qui caractérise ce que j'ai envie de raconter. Je pourrais appeler ce moment un moment de décolonisation. C'est ce que j'essaie d'exprimer dans le projet PRISM. Comment au même moment que j'apprenais le cinéma à l'INSAS c'est comme si je m'empoisonnais aussi par une forme unique de raconter des histoires qui soit celle de l'occident. Messiness rejoint la décolonisation de mon regard et comment je l'exprime dans ma manière de faire mes films en m'exposant, me fragilisant et en mettant en avant mon ignorance de cette histoire du cinéma.

STEFF: Kan je iets meer vertellen over jullie nieuwe project PRISM?

AN: Het verhaal begint bij mijn onderzoek naar de China Girls. Het idee daarvoor gaat terug naar de tijd waarin ik zelf nog film studeerde. Bij het vak videotechniek zei toen de docent van videotechniek: wil het meisje met de gaafste huid alsjeblieft voor de camera staan, want die moet gefilmd worden met een kleurenkaart. En zo geschiedde. Op dat moment stelde ik mezelf daar niet zoveel vragen bij. Pas later vroeg ik me af: wat is daar eigenlijk gebeurd? Waarom moest dat een meisje zijn? Waarom moest dat iemand zijn met een witte huid? Toen kwam ik op de China Girls; een procedé dat reeds sinds de jaren 20 gebruikt wordt om de kleur van de camera en van de printer af te stellen. Momenteel is er een heel archief met China Girls: beelden van witte vrouwen die heel even met een

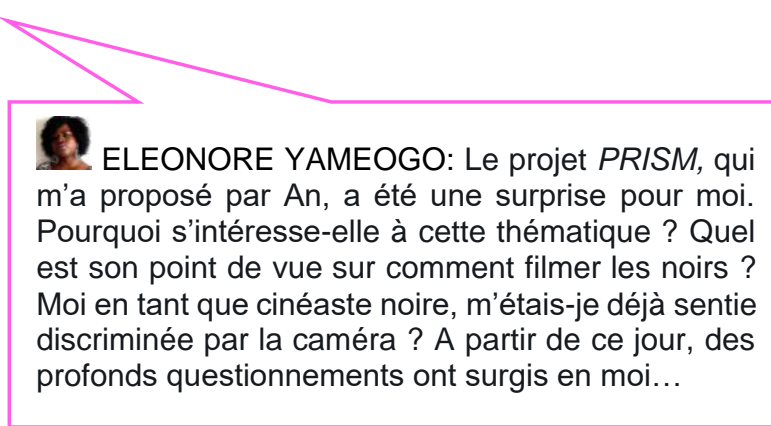
kleurenkaart gefilmd worden. Het procedé zit diep verscholen in de technologie van cinema. Aangezien het enkel door technici wordt gebruikt, krijgt de doorsneekijker het normaal gezien niet te zien. Het is echter een procedé dat aantoont dat de techniek van cinema bij voorbaat al bevooroordeeld is om witte huid goed in beeld te brengen en de huid van gekleurde mensen veel slechter in beeld te brengen. Dat komt vooral tot uiting in beelden waar je mensen met twee verschillende huidskleuren samenbrengt. Dat probleem zie je nog tot op de dag van vandaag. Ook al zijn er reeds een aantal verbeteringen, toch komt het nog steeds neer op de goodwill van de technici en van de mensen die voor de camera moeten staan en uren moeten wachten tot een juiste, goede representatie van hun huidskleur kan worden gecreëerd, als dat zelfs al mogelijk is. Vaak zijn die acteurs ook echt bijzonder teleurgesteld wanneer ze uiteindelijk de beelden van zichzelf zien: een donkerdere huid resulteert op beeld vaak in een vreselijke brei van tinten, waarbij geen enkele tint correspondeert met de werkelijke huidskleur.

3. ELEONORE: De mon point de vue, je pense il n'y a, en aucun cas, une forme de discrimination subtile. La peau noire n'est pas plus à son désavantage que la peau blanche. Face à une caméra : l'une et l'autre peuvent être mal exposés. Ce faux questionnement vient probablement du fait, que, par amalgame, le cinéma fait par les blancs est perçu comme au désavantage des noirs. Mais il est plus par l'idéologie, qu'un fait technique. On peut faire le procès de l'idéologie, mais il est faux de faire celui de la caméra.

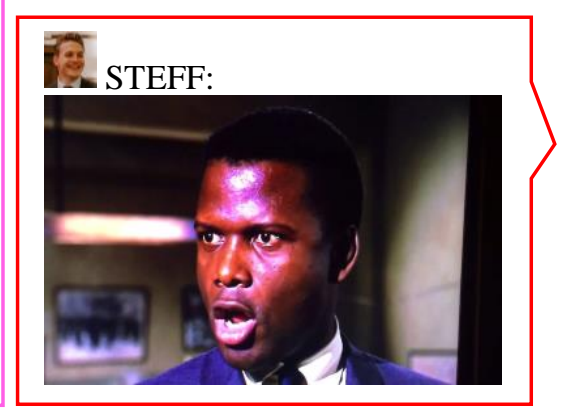

NATALIE: Youtube-clip: Sidney Poitier 'They call me Mister Tibbs!' In the Heat of the Night,

1967: https://www.youtube.com/watc h? $\mathrm{v}=\mathrm{ymrW}$ bZWTag

Daarbij is de documentaire interessant omdat je uitgaat van de paradox dat zodra je de realiteit filmt, je die realiteit transformeert en muteert. Je kan de realiteit nooit filmen zoals die is. Toch is er in onze westerse samenleving de drang om naar documentaire te kijken alsof het realiteit is. De traditie van de China Girls toont aan dat de camera niet zomaar een technologie is die de werkelijkheid 
objectief vastlegt. Het procedé wijst op een bepaalde voorkeur die ook in andere aspecten van het medium te merken valt, maar daarover heb ik geen precies onderzoek gedaan. Maar de technologie van de camera is hoe dan ook een uitvinding, door mensen geconstrueerd, en dus niet vrij van culturele vooroordelen. Juist daarom interesseren de China Girls me zo, en besloot ik er een film (Lili) en een tekst over te maken.

Maar ondanks de goede reacties op Lili zei een goede vriend van

\section{NATALIE: Inderdaad. Ik} werkte er zelf ook aan mee. me dat ik echt wel een witte film had gemaakt. En ik dacht: hoezo, witte film? Ik heb toch juist kritiek gegeven op de White Centricity? Die vriend zei dat ik dat zo wel kon bedoelen, maar dat ik wel enkel witte mensen had getoond en met een witte crew had gewerkt.te mensen had getoond en met een witte crew had gewerkt. Het was een witte film. Ik vond dat heel pertinente kritiek die ik absoluut niet kon weerleggen. Ik had al bij voorbaat in mijn onderzoeksvoorstel aan KASK geschreven dat de opvolger van Lili een documentaire zou zijn waar ik filmmakers van verschillende huidskleuren ga volgen in hun manieren om huid te belichten. Maar dat is nog steeds ik die als witte persoon een film ga maken over 'de ander'. Ik wou dat nu anders aanpakken en echt een collectieve film gaan maken. Toen is de omslag gekomen van ik als enige auteur naar ik die een cocreatief proces wou aangaan. Omdat ik nooit, never, jamais zal weten wat het is om een andere huidskleur te hebben. En die beleving of die embodiment, dat staat centraal in het project.

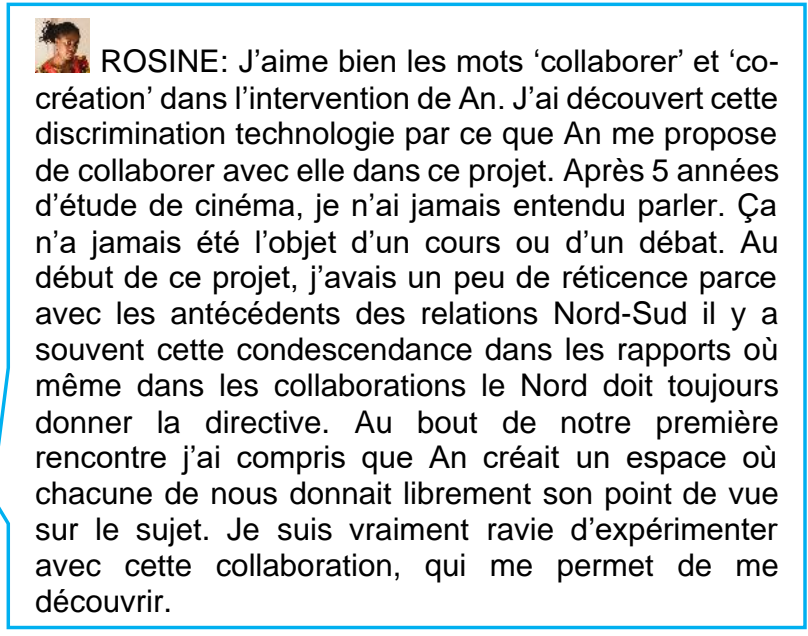

2 de collaborer avec elle dans ce projet. Après 5 années d'étude de cinéma, je n'ai jamais entendu parler. Ça n'a jamais été l'objet d'un cours ou d'un débat. Au souvent cette condescendance dans les rapports où même dans les collaborations le Nord doit toujours chacune sur le sujet. Je suis vraiment ravie d'expérimenter cette collaboration, qui me permet de me

\section{STEFF: Hoe ben je dan uiteindelijk bij Eléonore en Rosine terechtgekomen?}

AN: Het was een lang proces om mensen te vinden met wie ik een film kon maken over gekleurde huid. Ik wilde voorbij mijn eigen netwerken gaan, voorbij de mensen die ik ken. Ik wou ook uitgaan van multichronotopie. Een concept dat Stam en Shohat hebben ontwikkeld als alternatief voor interculturalisme en multiculturalisme. Zij benadrukken het belang om in film verschillende etnische achtergronden, verschillende klassen, verschillende soorten talen bij elkaar te brengen en dat op verschillende plekken ter wereld te doen. Dus ik dacht: ik ga dat ook proberen te doen. Dus ik zocht naar allerlei verschillende soorten mensen, van over de hele wereld. In een eerste fase van het project waren er vijf à zes makers: een antropoloog uit Japan, een Afro-Amerikaanse filmmaker, twee filmmakers uit Congo en dan nog Eléonore en Rosine.

Maar toen we een aanvraag deden bij het Vlaams Audiovisueel Fonds werd die niet goedgekeurd. Omdat we daardoor ook minder financiering kregen, hebben we het project moeten verkleinen. Er moest geknipt worden in het aantal filmmakers. Uiteindelijk zijn Rosine en Eléonore overgebleven omdat Eléonore in Parijs woont en Rosine in Brussel. Ook omdat ze beiden vrouwelijke filmmaaksters zijn. Met hen was er ook de meeste affiniteit: ze reageerden enorm positief op het project, we hadden

NATALIE:

Naar de norm van An en mezelf, tenminste... meteen een vibe. Concreet: Eléonore is een eerder klassieke filmmaakster uit Burkina Faso, die woont in Parijs. Zij is erg geëngageerd en werkt op een maatschappelijk relevante manier terwijl ze ook heel geïnteresseerd is in het vertellen van verhalen. Zij werkt vaak met fictie, met acteurs, actrices. Haar werk is heel interessant, in contrast met mij: ik werk veel meer experimenteel. Dan is er Rosine, zij is een unicum in wat ze doet. Ik vroeg haar vooral op basis van haar films. Die vond ik gewoon fantastisch omdat zij een heel andere benadering nam dan ik. Ook haar parcours als filmmaakster vond ik heel interessant: zij is opgegroeid in Kameroen en zij heeft daar van een NGO - want daar is geen filmschool - films leren maken. Zij heeft daarna voor televisie gewerkt, maar is uiteindelijk toch vanuit een soort van ontevredenheid naar het INSAS Brussel gegaan. Daar was ze de eerste zwarte vrouwelijke filmmaakster. Ze heeft daar heel hard moeten vechten, denk ik. Je ziet dat ook

\section{Q}

ELEONORE: Chaque personne est influencé par son environnement. De cette relation il y'a des circonstances qui nous invitent à prendre la parole, dans mon cas l'une de mes canaux d'expression est le cinéma. Je ne choisis pas mes sujets de façon intellectuelle, c'est en général, une idée qui émerge de mes observations de la vie, qui se fait persistante, qui fait écho en moi en tant qu'un être humain avec toutes ses références culturelles et spirituelle. Par la suite viens le désir de partager un point sur une thématique, d'en faire un film. En me référant à mes 3 documentaires je peux dire que j'aborde des sujets qui impliquent le Nord et le Sud dans des rapports parfois problématiques. in haar werk.
3. ELEONORE: Dans ma tendre enfance en Afrique j'ai été bercée par le conte. C'étaient des histoires qui nourrissaient mon imaginaire, éveillait des émotions, tout en apportant de quoi me construire en tant qu'une personne. Mes films se bâtissent sur les mêmes principes du conte. Les sujets de mes films peuvent être triste ou gaie, mais tout ceci repose solidement sur un fond édifier une personne ou une société. Mon public c'est l'être humain, car je traite des sujets qui le concerne, qui questionnent ses relations à l'autre, à l'environnement... porteur de valeurs qui puissent

LIESJE: Rosine denkt sterk na over hoe ze een blik werpt op degene die ze interviewt. Ze probeert de geïnterviewde die blik volledig zelf te laten bepalen.

AN: Ja, zij gaat erg persoonlijk om met de mensen. De vrouwen in haar films komen uit haar persoonlijke leefwereld. Bij Eléonore is dat niet zo. In die zin zijn ze erg complementair. Voor PRISM wil Rosine vertrekken vanuit het besef dat ze met haar witte man en kind nooit op de 'juiste' manier een familieportret zal kunnen maken. De verontwaardiging daarover is de motor voor wat zij doet. Eléonore werkt op haar beurt met een bekende Franse actrice die vertelt over alle problemen die zij ervaart als zwarte actrice in relatie tot het licht: de uren die zij moet wachten, de slechte 
manier waarop zij in beeld wordt gebracht. Ook over het feit dat zij als actrice enkel nog wil werken met zwarte lichttechnici, omdat die het best weten wat ze doen.

\section{LIESJE: Hoe gaat het geheel vorm krijgen?}

AN: Origineel wou ik van het geheel een cadavre exquis maken, een soort van collectieve tekening maar dan in film. Ook weer vanuit het idee na te willen denken over formats. Zo'n cadavre exquis in film kan misschien een aantal elementen van de klassieke documentaire doen ontsporen. Ik had het idee een scène te maken, die aan de eerste filmmaker te geven, die filmt het vervolg, en dat wordt dan weer aan de volgende doorgegeven. Dat was het idee toen we nog met vijf waren, maar op dat moment bevestigde ik wederom bepaalde machtsverhoudingen. Mijn feedbackgroep gaf aan dat het probleem was dat ik het format weer bepaalde. Dat ik als witte mens de eerste scène draaide en opnieuw degene was die alle regels bepaalde. Dat kwam weer erg in mijn gezicht. Ik wou het tegenovergestelde bereiken, maar ik was dat niet aan het doen.

NATALIE: Tijdens een van de Skypegesprekken hadden we het uiteraad over het collectieve aspect van de film, en hoe we van de verschillende fragmenten van de makers één film zouden maken. Rosine zei toen dat juist onze gesprekken samen - de dialoog - ervoor zorgen dat de drie filmmakers de uitwisseling van ideeën meenemen in enerzijds de scènes die ze nog moeten uitwerken en filmen. Ik interpreteerde dat als een soort 'embodiment' van die samenwerking: de onderlinge dialoog die door de drie filmmakers wordt belichaamd, en zo resoneert in de film. 


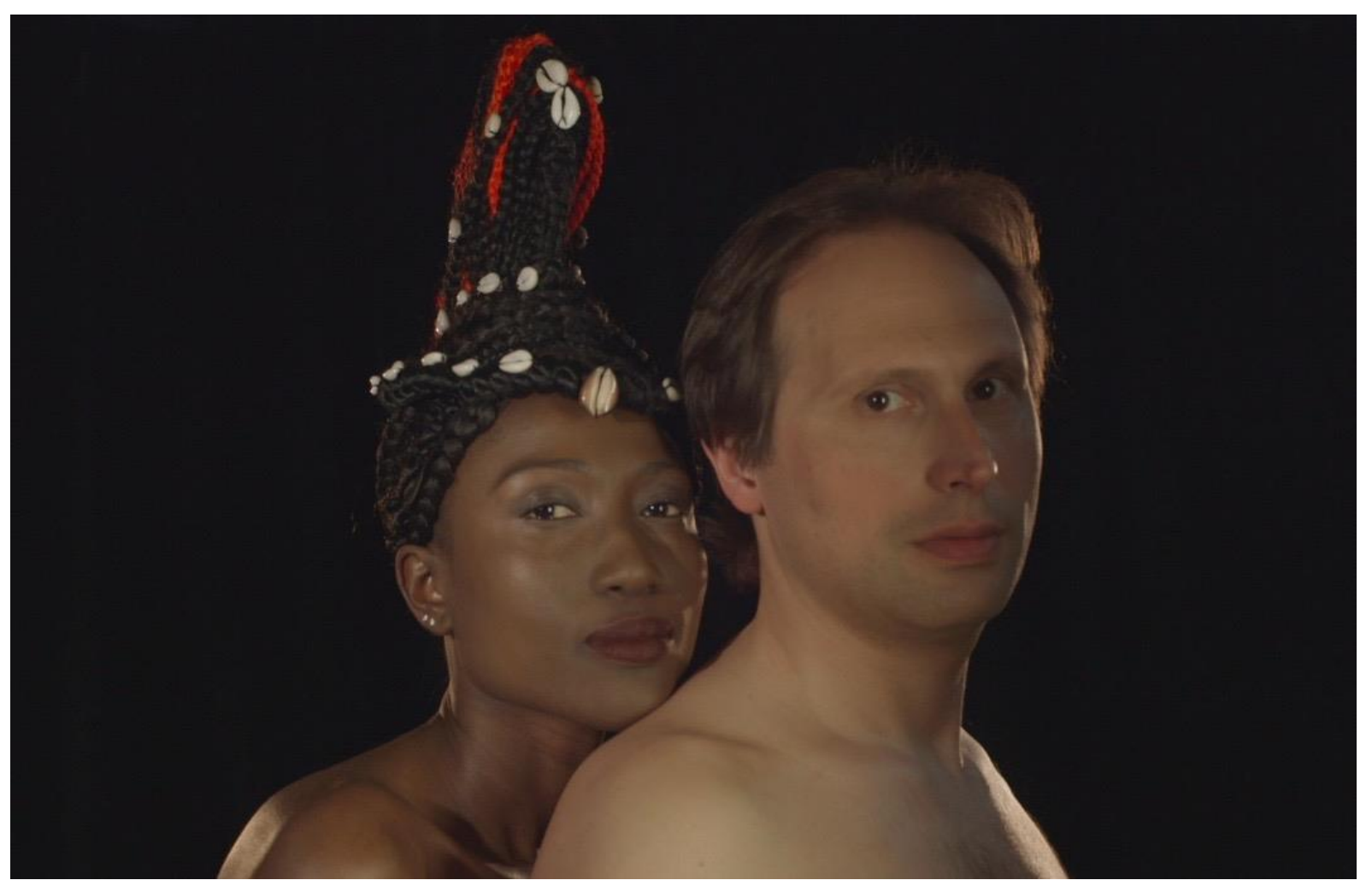

PRISM - Eléonore Yameogo @ Eléonore Yameogo 


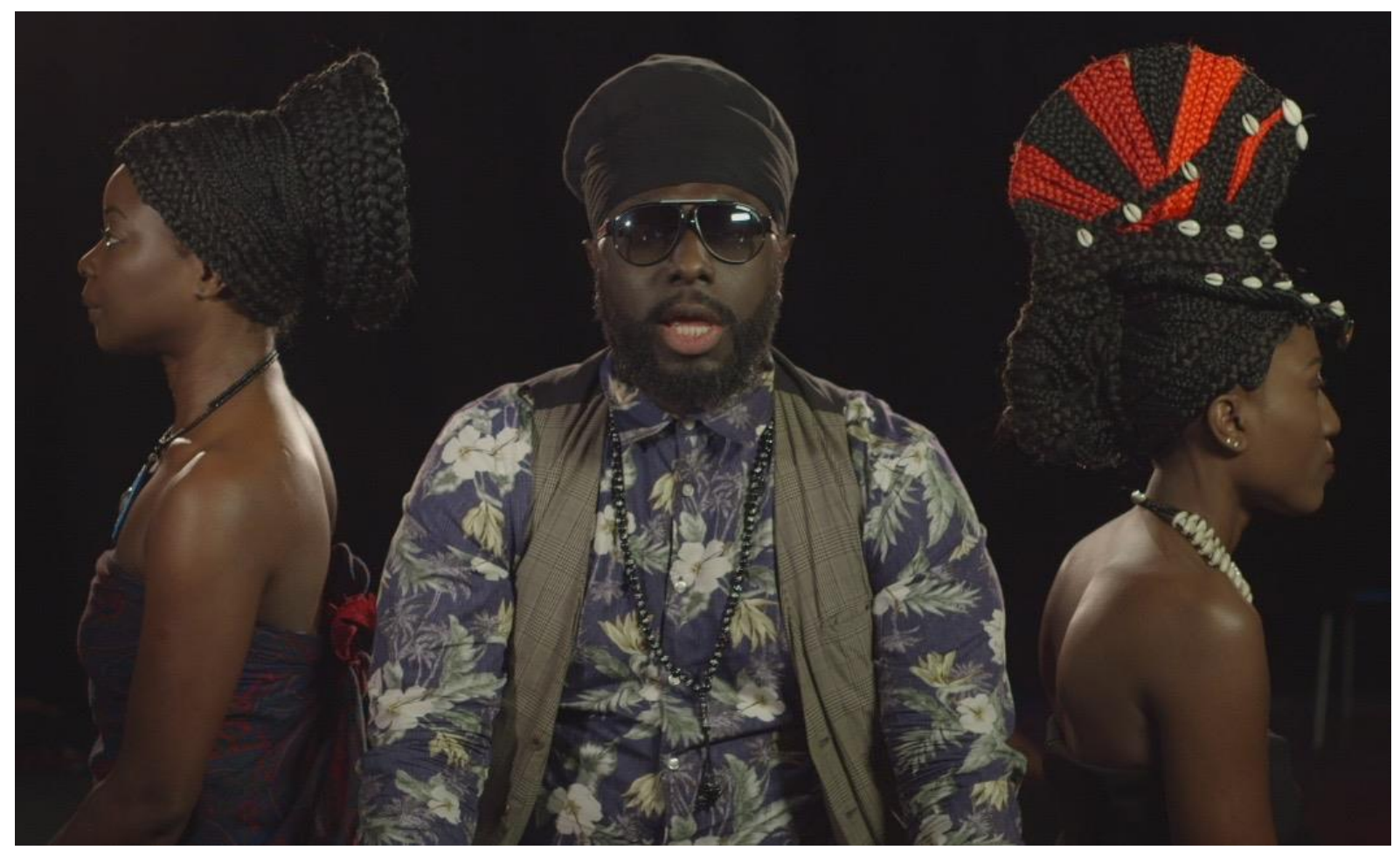

PRISM - Eléonore Yameogo @ Eléonore Yameogo 
Uiteindelijk hebben Eléonore, Rosine en ik drie dagen heel lang gebabbeld over het project, en onze intenties ermee en hoe daar verder mee te gaan. Toen hebben we beslist het idee van het cadavre exquis te laten vallen. Ik heb daar toen duidelijk gemaakt: die beelden die ik al maakte, mogen eventueel in de vuilnisbak belanden. Alles mag. We trekken het volledig open. Dus toen besloten we in plaats van het cadavre exquis eerder een soort gesamtkunstwerk te maken met drie. Sindsdien hebben we veel geskypet; heeft Rosine haar deel geschreven, Eléonore haar deel. leder filmt apart en vervolgens gaan we samen monteren. Een belangrijk aandachtspunt voor mij is: hoe kan ik mijn eigen rol die zeker geprivilegieerd is - zelfkritisch beoordelen?

\section{ROSINE: Il est important de se}

questionner, de répéter cette démarche même sur des choses qui nous paraissent évidentes. Mon parcours m'a toujours confronté à l'autre et à ses différences. Au Cameroun, je me suis formé dans une ONG italienne. J'ai travaillé en télévisons où j'ai collaboré avec des camerounais, sud-africains et des européens. Je viens en Belgique pour étudier le cinéma occidental avec la conviction de rentrer dans mon pays après pour faire du cinéma. Je tombe amoureuse d'un français avec qui j'ai deux enfants. Comme si la vie voulait que je me confronte à la différence de l'autre. Quand on vit dans une monoculture, on doit faire une démarche individuelle d'aller vers l'autre ; c'est ce que An a fait par PRISM et c'est ce Steff et Liesje font par cette interview. Les différentes étapes de mon parcours personnel m'ont permis de rencontrer l'autre, de mettre à sa place parfois, de déplacer mon regard et découvrir à quel point l'histoire de l'autre pouvait être connecté au mieux. Tout le contraire de ça que ce système dans lequel nous vivons veut nous faire croire en jouant sur nos différences. Le projet PRISM et être intégré dans le groupe de Speculative Documentary me permets de me confronter à d'autres univers, d'autres arts et d'autres formes de pensée. C'est juste fabuleux pour moi car j'apprends, je me nourris et je grandis.
LIESJE: Het is inderdaad niet gemakkelijk om je daar altijd bewust van te blijven, maar wel belangrijk. Hoe kunnen we problemen aankaarten zonder in die typische white savior rol te vervallen? Het is heel moeilijk om het juist te doen, maar het is nodig om daar actief bij na te denken.

STEFF: Je zit misschien met een 'goede intentie' in je hoofd, maar dat is niet voldoende. Je moet jezelf voortdurend herdefiniëren.

AN: Dat is wat ik ook merkte bij dit project. Ik dacht met dat cadavre exquis te werken, met multichronotopie te werken, allemaal ingewikkelde begrippen. Maar dat werkte contraproductief. Het draait nu meer rond het simpele idee van samen aan tafel te kunnen zitten, samen na te kunnen denken, constant bewust te blijven van je eigen privilege.

ROSINE: Ces trois jours de discussion toutes les trois ont permis de nous approprier le projet à notre tour et de lui donner une forme commune. Cette phase de travail a été très cruciale pour moi car je redoutais la collaboration. J'avais en moi les traumatismes des exercices de groupe à I'INSAS où je me sentais très loin de ce qui se discutait. J'étais noyé, ma différence ne comptait pas. II n'y avait pas de place pour donner ce que j'avais en moi. C'est ce que j'exprime d'ailleurs dans ma partie dans PRISM. Ce moment de rencontre m'a rassuré et le basculement c'est opérer $P R I S M$ devenait un projet que je pouvais porter et défendre car je pouvais exprimer des choses à ma manière sans avoir à me battre pour ça.

Het is heel ingewikkeld, maar samenwerken met Eléonore en Rosine is echt fantastisch. En dan is er ook nog Natalie natuurlijk. Zij is meer dan een producent. Omdat zij ook redacteur is voor Etcetera, is ze supergevoelig voor de thema's waar wij mee werken. Zij is constant een ethische barometer die toont of we niet aan het ontsporen zijn. Zij heeft ook die feedbackgroep mede samengesteld en een aantal mensen gekozen die ik zelf niet kende, juist die mensen die me er als eerste op wezen dat ik toch wel weer de regels van het spel aan het bepalen was. - Ik bedenk nu dat het feit dat ik hier wel weer het eerste interview geef, op zich ook wel weer problematisch is.

LIESJE: Inderdaad, en daar zijn we ons erg van bewust. We zagen hoe jij ervoor koos om jouw materiaal dat reeds gefilmd was te onderwerpen aan Rosine en Eléonore. We zagen ook hoe Rosine zich onderwerpt aan haar onderwerpen, aan de mensen die ze interviewt. Zo onderwerpen wij onszelf nu aan Rosine en Eléonore door hun vrij spel te geven met het resultaat van dit interview. Zij mogen We vragen hen om actief mee te denken: reageren, weghalen, toevoegen. Ze

STEFF: Het is opvallend hoe snel we dreigen te vervallen in het 'zij mogen'-discours. Dit herschrijven is een confronterende oefening. Maar broodnodig, zo blijkt. mogen Ze kunnen dit ook gewoon weggooien, zeggen dat ze met niets akkoord gaan. Als we dit gesprek eenmaal vorm hebben gegeven, willen we dat we het naar hen doorsturen met de boodschap: doe ermee wat je wil. Scheur het ook maar gewoon in stukken als je er niks van vindt. Dit is niet hét eindpunt. Het is slechts een van de verschillende materialen waarmee zij iets kunnen doen. Van ons krijgen ze tabula rasa. Voor iedereen geldt maar één principe: tabula rasa!

jij reeds hebt gemaakt? Kunnen zij die manipuleren?

STEFF: Is het nog altijd zo dat zij ook aan de slag kunnen gaan met de beelden die

AN: Ja, een van de eerste ideeën was om de volledige film in filmscholen te maken. Hier in Gent, in KASK of in Burkina Faso, maar ook op plekken waar geen filmschool is. Maar ook dat idee is...

STEFF: Gesneuveld (lacht). 
AN: Gesneuveld (lacht). Inderdaad. Het idee volgde uit mijn vorige films, die zich telkens

2. ROSINE: L'idée de filmer dans une école s'est discuté entre nous trois. Et chacun de nous était libre après de le faire ou pas. Pour moi cette idée me parlait très vivement car l'école est symbolique de la construction d'une idéologie. Pour moi il me semblait évident que j'allais tourner à l'INSAS, où j'ai étudié, pour essayer de questionner cette idéologie à partir des professeurs, la véhicule et son impact sur des gens comme moi qui viennent d'ailleurs. afspelen op een cultureel symbolische plek: Lili bij de Vlaamse omroep VRT en Cherry Blossoms in het Europees Parlement. Filmscholen zijn voor mij ook zo'n symbolische ruimte waar processen van traditie en canonisering maar ook van uitsluiting en discriminatie erg tastbaar zijn. De plaats van een filmschool is dus heel relevant. Rosine gaat wel nog filmdocenten interviewen, vanuit haar verontwaardiging hierover. Eléonore gaat echter niets in een filmschool doen. Ikzelf ben wel in KASK gestart. Ik maakte een lange, doorlopende one take van buiten naar binnen die een gesprek volgt tussen twee vrienden. De man geeft de vrouw een compliment en zegt dat haar haar goed zit. De vrouw begint op haar beurt over de potloodtest in ZuidAfrika, waarbij burgerrechten worden toegekend aan iemand op basis van het feit of een potlood in het haar blijft zitten of niet. Dit komt echt uit het leven van de actrice. Vervolgens komen ze in de studio, waar een soort van kleurtest begint waarbij de lichtsetting verandert en je hierdoor de witte man soms veel beter ziet dan de zwarte vrouw. Maar deze scène is heel open en nog voor veel interpretatie vatbaar. Rosine had bijvoorbeeld meteen het idee geluid in te voeren bij de kleurtest-scène, die nu nog stom is. Ik heb nog enkele close-ups gemaakt van het decor, die nog ergens anders gebruikt kunnen worden. Maar we zijn er dus echt volop samen over aan het nadenken. Mijn gevoel is 'doe maar!' (lacht).

ROSINE: Je mets en scène la reconstitution avec une actrice le tableau de MarieGuillemine Benoist Le portrait de la Negresse.

Je fais les allez retour entre la mise en place de ce tableau et mon parcours personnel. Je vais à l'INSAS pour questionner la colonisation du cinéma occidental sur les autres formes de cinéma. C'est quoi le Sud et c'est quoi le Nord au le cinéma ? Je questionne l'héritage de mon mariage avec un français dont le grand-père était un colon qui a filmé l'Afrique. Cet héritage est-il aussi mon héritage ? Comment je transmets ça à mes enfants? Je questionne ma propre colonisation en tant que réalisatrice africaine dans un système régit par les blancs et comment ce poison m'affecte et affecte mon

LIESJE: Dat is een mooie attitude. In de tekst die je schreef over Lili ging het niet alleen over ideologische discriminatie maar ook over praktische, technologische discriminatie: de manier waarop er een racial bias kan zitten in technologie:

The Caucasian skin is used as a reference for the grading of camera and printing, ultimately excluding people of colour, as they do not conform to this implicit norm. (...) Very problematic about this tradition is the fact that it is hidden deep in the confinements of the technological processes of cinema (2017).

De manier waarop camera's zijn ingesteld op de witte huidskleur wordt altijd ingedekt aan de hand van een pseudowetenschappelijk, zogenaamd objectief discours, terwijl het in feite uiterst subjectief is omdat die norm door mensen is vastgelegd, en dus potentieel racistisch is. Is dit een probleem dat zich vooral in analoge film voordeed of is het overgedragen op digitale film? In hoeverre is er ook sprake van de problematiek in materiaal op andere continenten? Is het afhankelijk van de mensen die het toestel bedienen? Het is voor ons nog erg onduidelijk.

\section{Q}

ELEONORE: Pour moi, il est évident que cette confusion vient plutôt du fait que certains essais de pellicules américaines dans les années 50 et 60 se faisaient avec un modèle à la peau blanche et que donc l'exposition était calculée en fonction. La même chose aurait pu être faite avec un modèle a la peau noire mais ce n'était pas la cible du marché visé par les publicitaires de l'époque. Il faut alors bien veiller à ne pas confondre pellicule et caméras. Les pellicules ont fait aussi d'énormes progrès, elles n'existent presque plus aujourd'hui, remplacée bien souvent par des capteurs ultra performants qui captent les basses lumières avec un détail étonnant, ce qui réduit en bouillie la fallacieuse argumentation de la caméra discriminatoire. 


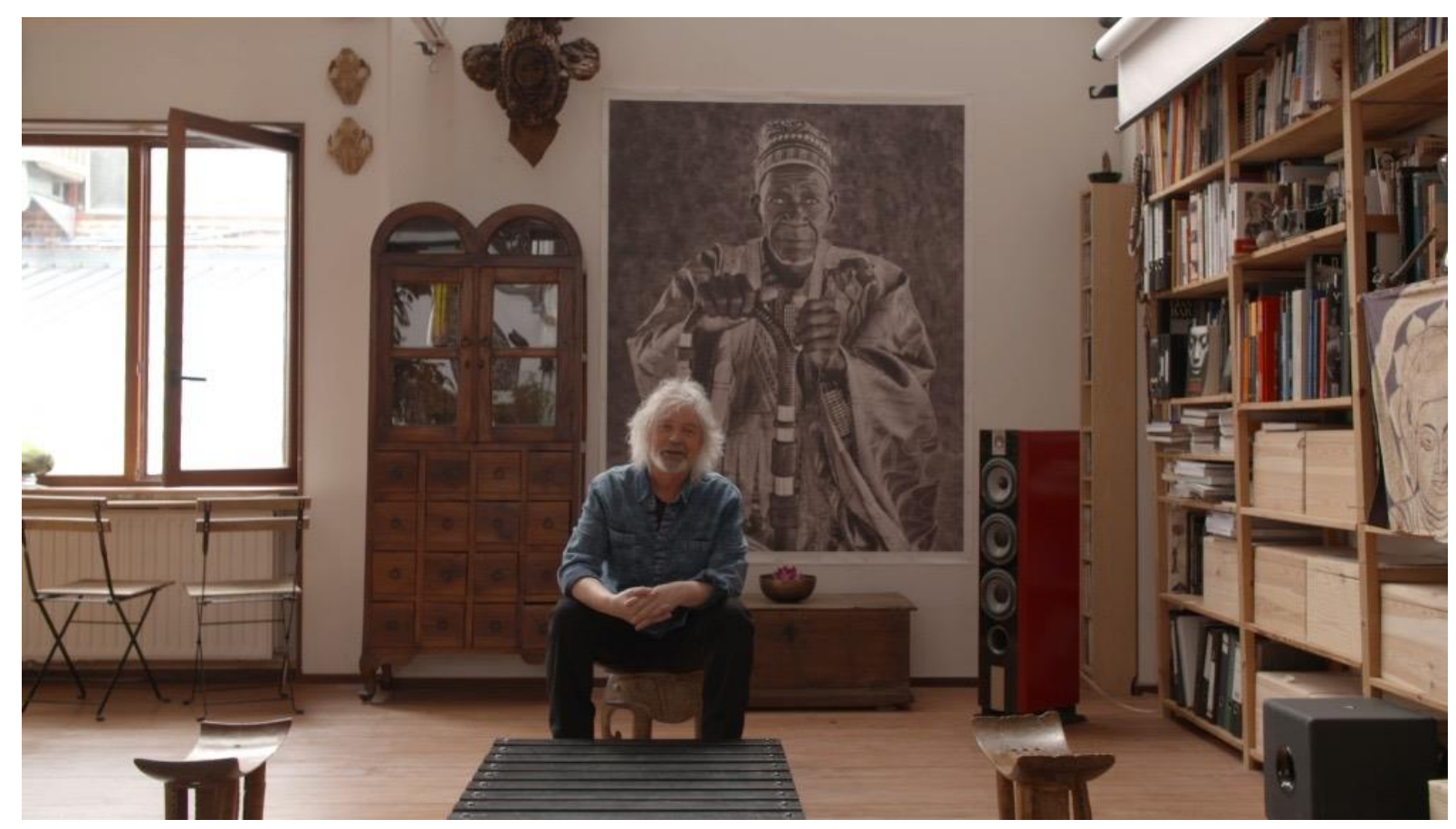

PRISM - Rosine Mbakam (C Rosine Mbakam 


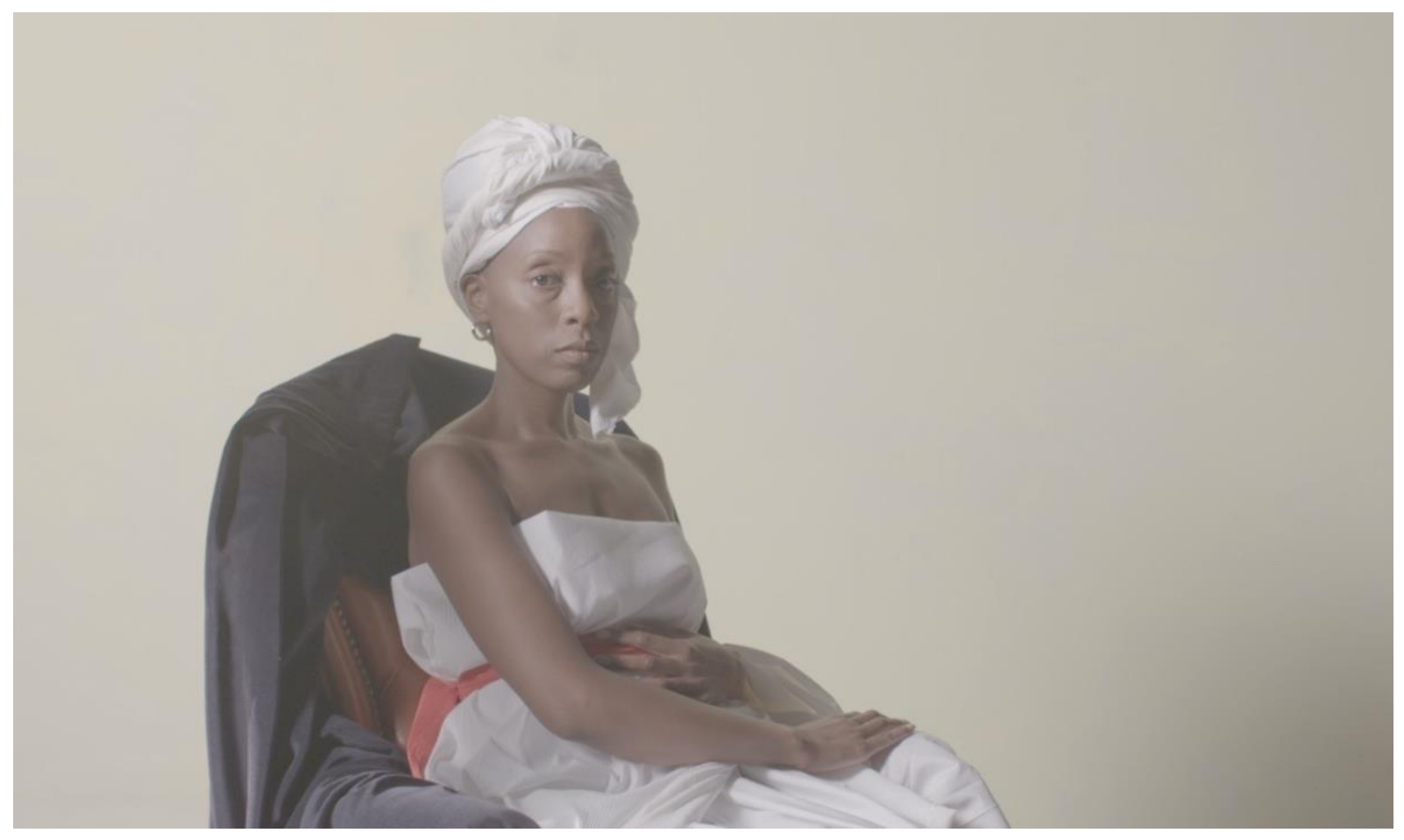

PRISM - Rosine Mbakam (C Rosine Mbakam 
AN: Ja, voor mij ook (lacht). Ik heb tot nu toe nog geen duidelijke antwoorden gevonden op die vraag. Het was een traditie bij analoge film maar het is, raar maar waar, meegegaan in de overgang naar digitale film. Ik heb kleurenkaarten binnengekregen van Photoshop waarin een witte vrouw met allerlei gekleurde objecten wordt gefilmd. Ik heb ook een beeld gekregen, uit andere software, van een vriend die professioneel fotograaf is. Die foto... Ik noem dat echt een man's cave. (lacht). Je ziet een vrouwelijk achterste, je ziet auto's, horloges... Onwaarschijnlijk dat dat nog altijd gebruikt wordt als een zogenaamd neutraal technisch procedé. Het heeft dus wel degelijk doorgewerkt in de overgang naar digitale film en zelfs naar softwareprogramma's. Het is complex, en er wordt te weinig onderzoek naar gedaan.

ROSINE: Je n'ai pas fait des recherches là-dessus mais si je me réfère aux recherches d'An et à ce qu'elle écrit, filmer les autres peaux demande du temps et plus d'énergie. Seulement pour ça les choses devraient être repensé.
LIESJE: Dat tekort zegt dan ook iets over het feit dat niemand zich vragen stelt bij de technologie.

AN: Absoluut. Onlangs was ik op een conferentie van Europese filmscholen in Keulen. Weinig mensen kenden het fenomeen van de China Girl. Terwijl het een goed voorbeeld vormt van racisme in de technologie van audiovisuele media. Ik zeg niet dat elke camera racistisch is, maar het medium werd wel ontwikkeld om de witte huid zo kwalitatief mogelijk in beeld te brengen. Met als gevolg dat andere huidskleuren minder goed belicht worden. Velen staan daar niet bij stil. Slechts enkele onderzoekers hebben ermee gewerkt: Genevieve Yue, Richard Dyer en Lorna Roth. Dat onderzoek moet worden voortgezet. Ik doe dat vooral op artistiek vlak.

ELEONORE: La principale
différence entre les peaux blanches et
noires n'est pas due à la couleur mais
plutôt à la densité. L'exposition est alors
essentielle. C'est la bonne exposition,
un choix artistique et technique à la fois,
qui permet de révéler la beauté des
peaux noires, en prenant en compte leur
teinte, leur texture et en prenant compte
une règle fondamentale des peaux
noires: son faible facteur de réflexion de
la lumière. Ce facteur de réflexion n'est
pas une invention raciste, c'est une loi
de la physique (ce que j'essaie de
démontrer lors du tournage de ma
partition, avec des objets de couleurs
différentes). Quand on règle une
caméra, on calibre aussi bien le noir que
le blanc qui ne sont, pour une caméra,
que deux valeurs électriques (en
microvolts) permettant d'analyser
l'énergie des photons perçus par le
capteur.

STEFF: Wat verwacht je als output bij de toeschouwer? Binnen de avantgarde cinema zijn er veel makers die geven om wat het publiek uit de film bezig?
Et) LIESJE: @ Steff: Zou jij die afbeelding hier nog kunnen invoegen? Om de een of andere reden lukt mij dat niet...
STEFF: @ Liesje: De witte man die de beelden van de man's cave invoegt...

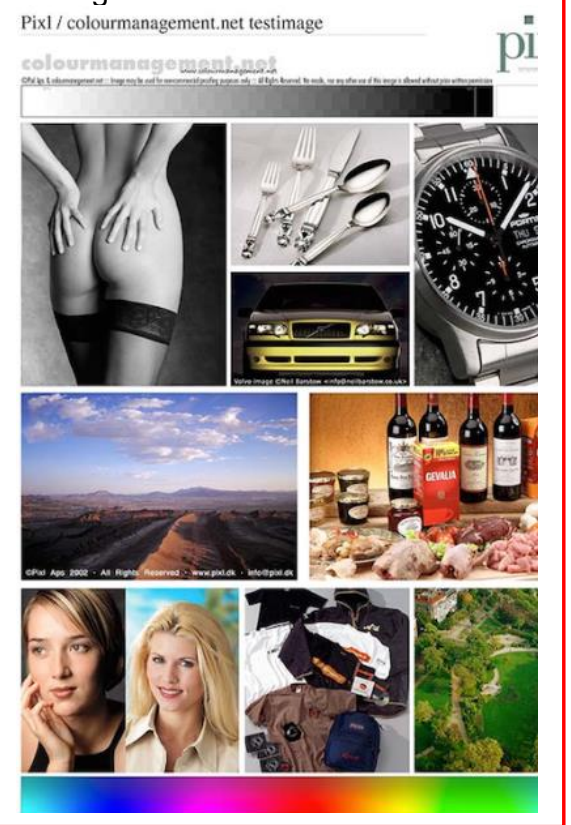
haalt. Voor deze makers is het ook belangrijk hoeveel mensen bereikt worden. Soms worden films daarom zelfs aangepast en toegankelijker gemaakt. Houdt dat jou ook

AN: Dat is een belangrijke maar moeilijke vraag. Trinh Minh-Ha heeft er iets moois over gezegd: 'Een film is als een fles met een boodschap die je in de zee gooit.' Je weet niet of die aankomt. Dat is echt zo voor mij. Voor Eléonore is het publiek enorm belangrijk. Het moet voor haar een film zijn die voor een groot publiek zou kunnen werken. Zij wil PRISM niet opsluiten in een kleine niche. En ze heeft een punt. Ik wil dat de film in andere contexten wordt getoond. De films die ik maakte in China, Guatemala en Japan zijn ook daar vertoond. Zo probeer ik een soort spinnenweb te creëren van filmfestivals en andere netwerken die klassiek genomen niet als eerste zouden worden

aangesproken, maar wel door de film geïmpliceerd zijn. Voor PRISM willen we ook breed mikken: niet alleen vertoningen op Europese festivals maar ook in Burkina Faso en Kameroen. Ook voor Rosine is dat belangrijk. We hebben samen een documentaire workshop gegeven aan studenten in Gent. Zij neemt een aantal films van die studenten mee naar Kameroen om daar

NATALIE: Voor mij als producent is het heel boeiend om de verschillende motivaties, focuspunten en stijlen van de drie filmmakers te observeren, die variëren van conceptueeltheoretisch via poëtisch, persoonlijk en activistisch tot documentaire en publieksgericht. jonge filmmakers in contact te brengen met dit werk. Hetgeen zij niet vond toen ze ernaar op zoek was. Die awareness-functie van film is belangrijk. Film dient voor mij als middel tot gesprek zonder de pretentie aan te nemen om hapklare antwoorden te bieden. Maar film mag niet geïnstrumentaliseerd worden voor discussies. la maison familiale et s'envole et ne nous appartient plus. Peu importe ce qu'il devient plus tard quand on le voit, on le contemple avec joie et on ce qu'on a quand bien fait de le faire cet enfant.

2. ROSINE: Moi je dirai qu'un film est comme donner naissance à un enfant. On le porte en nous. On lui donne la vie, on le nourrit, l'éduque et lui transmet plein de choses. Un jour, il sort de 
ROSINE: Quand on fait un film, comme un enfant on lui souhaite le meilleur et sur qu'il rentre en connexion avec le monde. Je souhaite une belle vie à ce film. II aura une belle d'où je viens c'est ce que je présents. Le besoin que j'aie ressenti à me questionner sur le sujet. Je le partage avec plein de gens dans le monde. Je suis actuellement au moment où je vous écris en tournée aux États-Unis avec mes deux films. A chaque fois le public me demande c'est quoi, mon prochain projet ? Je leur parle de $P R I S M$ et les gens sont enthousiastes. L'été dernier j'ai lancé au Cameroun une caravane cinéma où on allait de village en village et de quartier en quartier pour montrer des films. Dans le seul but que les gens aient accès à leurs propres images et leur réalité et $P R I S M$ en est une « représentation de leur image » qui pose une question importante en ce moment au Cameroun et en Afrique.

STEFF: Ik herken hierin wat je reeds in het begin van ons gesprek zei: sommige makers hebben een uitgesproken politiek doel terwijl andere meer op engagement mikken. Bij jou gaat het dus eerder om engagement?

AN: Ja. Maar zonder de film te instrumentaliseren. Film is geen vehikel. Het gaat ook altijd om nadenken over vorm en op welke manier dat een uitdaging kan zijn. We mikken op engagement en awareness bij de toeschouwer. Maar subsidiekanalen verplichten ons om tot een bepaalde categorisering te komen. Voor het VAF is het belangrijk dat films mikken op klassieke grote A-festivals; die vertonen uitsluitend premières en zijn super competitief. Wordt je film vertoond op een lokaal festival, dan zou hij minder waard zijn. Wij proberen echter het belang te duiden van de andere wereld: een artistieke, museale en beeldende. Het publiek is dus een veelkoppig monster. Misschien hou ik daarom wel van de eenvoud van Trinh's metafoor, dat 'flesje'. Je kan alles doen wat je wil, van het uitdenken van mogelijke scenario's tot het actief inzetten op publiekswerking... Je weet het eigenlijk nooit.

LIESJE: Vooral omdat je niet alleen werkt. Elk van jullie heeft waarschijnlijk een eigen idee en persoonlijke doeleinden. Die moeten op een of andere manier ook assimileren.

AN: Ja. Lili zat volledig in het eurocentrische kader. Het is niet vertoond op Afrikaanse festivals of plekken in Azië of LatijnsAmerika. Door met Rosine en Eléonore te werken, wordt het opengetrokken. Ze brengen mij met netwerken in contact die ik helemaal niet kende. FESPACO bijvoorbeeld, in Ouagadougou waar hun nieuwste films onlangs in première gingen. Ik denk dat FESPACO bijvoorbeeld niet eens op de lijsten van filmfestivals staat. Dat soort eurocentrische categorieën is parallel aan het fenomeen van de China Girls. Het is een andere veruitwendiging van dezelfde

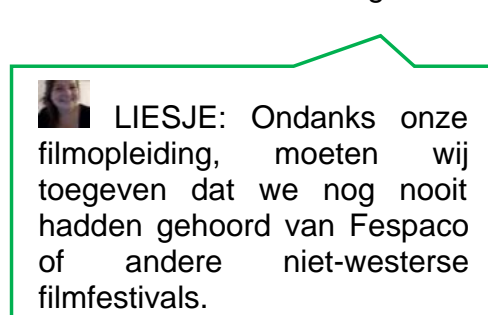
filmfestivals.

\begin{tabular}{ll|} 
- & STEFF: \\
- & https:///fespaco.bficanwomenincine \\
& $\frac{\text { ma.blogspot.com/2019/02 }}{\text { Lespaco-2019-chez-jolie- }}$ \\
& coiffure-byde.html \\
- & $\frac{\text { https://www.voaafrique.co }}{\text { m/a/gros-plan- }}$ \\
\hline
\end{tabular}

9. ELEONORE: Le spectateur c'est lui qui donne un sens à mes films car mes sujets portent sur l'humain. L'avis donc du spectateur est capital pour la réalisation des projets suivants. J'aime beaucoup les débats à l'issue de mes projections. Mais c'est étrange de constater que pour un point particulier d'un film, on puisse avoir des critiques très différentes, voire contradictoires. Quand on est auteur, réalisateur d'un film, on comprend très vite, qu'il faut permettre à chaque point de vue d'exister mais, surtout de prendre soin de son propre point de vue afin de rester debout...

2. ROSINE: II est difficile d'être neutre dans la société actuelle. II faut s'engager, prendre position, choisir un peu son camp. Tout devient politique. En travaillant sur $P R I S M$, je me suis découvert et ce n'était pas très beau ce que j'ai découvert. Je l'ai accepté et je le donne au spectateur. An et Eléonore ont fait la même chose. Montrer mes fragilités est un engagement. Je crois qu'en tant que comme spectateur on s'engage en choisissant les films qu'on va voir. Ceux qui viendront voir PRISM savent qu'ils vont être bousculé, questionné et vont cheminer avec en faire ce qu'ils veulent. J'ai confiance au public. problematiek.

LIESJE: Ja, en dat is triest. We mogen nog zoveel interessante filmmakers hebben, waaronder $u$, die enorm veel engagement willen aangaan. Maar er blijft een netwerk of grotere structuur die jullie tegenhoudt. Hopelijk kunnen projecten als PRISM het besef doen groeien dat we ook buiten de lijst moeten kijken.

2. ROSINE: Je ne suis pas très étonnée de tout ce que vous dites. J'en parle d'ailleurs dans ma voix off dans $P R I S M$. La culture européenne se veut homogène alors que son histoire nous dit le contraire. Elle se veut être la pensée et le centre du monde parce qu'elle regarde le reste monde de son nombril sans jamais déplacer son regard. A un moment, cette Europe qui se veut être le centre du monde se sentira obligé de regarder les réalités du monde. C'est juste une question de temps et PRISM n'est qu'une petite réponse à ça. 
STEFF: Hopelijk kan Trinh Minh-Ha's boodschap-in-een-fles ook op een hoger niveau doordringen.

LIESJE: (lacht) Exact. Jullie project is uniek omdat het zowel ideologische als technologische maar ook structurele discriminatie blootlegt. In de filmwetenschap praten we vaak over vorm en inhoud maar weinig over het hoe of de mogelijke beperkingen die makers ervaren door subsidieweigeringen en nog minder over de invloed van overkoepelende systemen zoals het Vlaams Audiovisueel Fonds.

9. ELEONORE: II n'a aucun problème pour filmer les acteurs noirs avec les mêmes caméras qui filment les blancs. Se pose t'on la question lorsque des réalisateurs blancs filment des acteurs noirs dans leurs films ? Se pose t'on cette question lorsqu'on regarde un film de Spike Lee ? Denzel Washington, Will Smith, Morgan Freeman, etc... Ou encore plus près de chez nous : Aissa Maiga ou Omar Sy? Prenons un exemple : Uwe Omer, un photographe allemand qui a su magnifiquement photographier les modèles blacks pendant les années, et qui a su mettre en valeur toute la plastique des femmes noires qu'il filmait (f.e. livre « black ladies »). Ou Jean-Philippe Goulde, qui a su mettre en valeur Grace Jones, en la filmant pour ses clips et pour ses publicités très connues. Où est donc la discrimination subtile? film tonen in de aanwezigheid van een publiek waarmee je daarna in dialoog treedt, vind ik het leukste wat er is (lacht).
AN: Rosines anekdote is exemplarisch: de eerste film over Afrika die zij ooit zag was een film, gemaakt door witte mannen. De representatie van zichzelf is in die zin reeds gekolonialiseerd.

LIESJE: Precies. Ze kan enorm goed verwoorden hoe haar blik op die manier geïnternaliseerd raakte. Hoe zij leerde om zichzelf te bekijken via een westerse blik. Het is daarbij interessant hoe het lijkt dat Rosine en Eléonore elk een andere strategie hanteren om dit aan te kaarten. Rosine probeert los te komen van de westerse blik en verschaft haar toeschouwers een blik van binnenuit. Eléonore daarentegen probeert de blik om te keren door vanuit haar eigen beleving naar het Westen te kijken. In ieder geval in de film Paris mon Paradis (2011). Het is mooi dat jullie verschillende strategieën zullen samenkomen in PRISM.

AN: Ja. En hoe onze ideeën toch ook heel overeenkomstig zijn, ondanks de verschillende stijlen die we hanteren. We zien film alle drie als een collectieve beleving of happening. De feedback van het

2. ROSINE:
J'ai hâte de
voir comment
le film PRISM
réagira avec le
public.

LIESJE: Je gaf reeds aan dat Trinh Minh-Ha een grote invloed uitoefent op je eigen praktijk. Het ethisch-esthetisch concept 'Speaking Nearby' is erg belangrijk voor haar. Probeer jij het ook toe te passen?

AN: Ik herinner me dat Minh-Ha op een festival zei dat er al zoveel over de filosofische achtergrond van het begrip 'Speaking Nearby' geschreven is terwijl het in haar ogen iets heel praktisch is. Het gaat echt om dicht bij de mensen staan. En de camera ook dicht zetten in plaats van afstand creëren. Zo reflecteer je op de relatie tussen filmmaker en onderwerp. Natuurlijk schuilt er meer achter, maar dat is de essentie. Er schuilt namelijk een machtsrelatie tussen subject en object in film die je kan analyseren. Die (zelf)reflexieve praktijk is gestart in het werk van Minh-Ha, bijvoorbeeld in Reassemblage (1983), waarin ze voor de eerste keer 'Speaking Nearby' in de voice over vermeldt.

\section{LIESJE: En je probeert het zelf ook te doen?}

AN: Enorm. In mijn vroegere films door letterlijk zelf in de film te staan. Een van mijn eerste films, Visitors of the Night (1998), gaat over een Chinese polyandrische samenleving. Eigenlijk gaat de film vooral over de constructie die ik in mijn hoofd maakte over polyandrie en hoe die totaal niet strookte met de realiteit die zich voordeed. De film toont zelfreflectie en zelfkritiek. Dat nadenken over je eigen rol binnen de film vind ik heel belangrijk. Eléonore wou daarom initieel een scène filmen met ons drie in beeld. Wij verschillen allen namelijk ook erg van huidskleur.

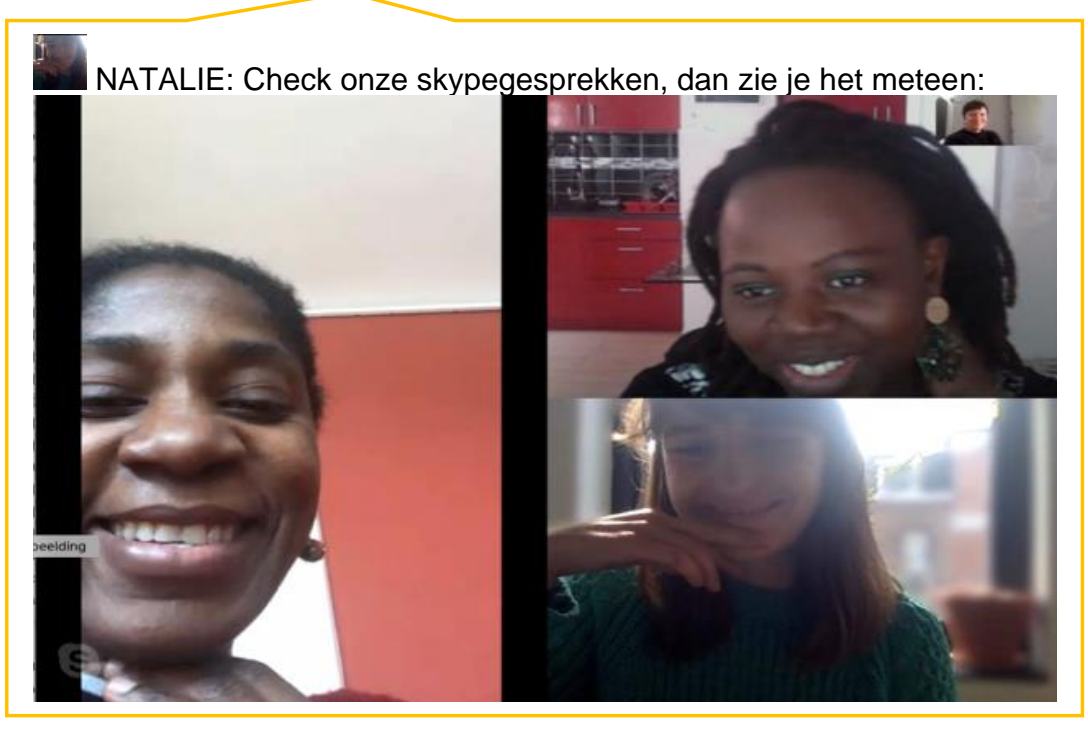

Q

ELEONORE: D'ailleurs il n'existe aucune possibilité de faire une caméra « qui filme mieux les noirs » car elle serait en tout point identique à celles existant aujourd'hui. Je pense qu'il faut détacher le problème technique de la caméra qui n'est qu'un outil, de celui du regard les cinéastes et photographes. Comme Alain Gomis a dit : «Lorsque les européens filment le continent, ce n'est qu'à travers un regard extérieur, celui du colonialisme, offrant aux différents peuples une représentation erronée. „ Alain parle de l'idéologie véhiculée par le film ou d'une sous exposition technique volontaire de l'image ? Associer l'invention de la caméra à une discrimination des noirs est très complexe. A-t-on, une seconde, imaginé d'associer l'invention de l'imprimerie à une discrimination des noirs ? Pourtant on a publié des livres discriminatoires. La main, outil sublime du bout du bras, peut caresser mais peut aussi étrangler. Condamne-t-on la main ? 
LIESJE \& STEFF: Veel vragen blijven na dit interview nog onbeantwoord. Is er sprake van een verborgen of subtiel technologisch racisme in de werking van filmcamera's? Eléonore pleit van niet. Waarom is het dan zo moeilijk om twee lichamen met een verschillende huidskleur samen op beeld vast te leggen? Het antwoord ligt wellicht vooral bij de bereidwilligheid van het individu achter de camera. An, Rosine, Eléonore en Natalie benadrukken allemaal het belang van zelfreflectie en -kritiek. Wij probeerden net zo kritisch te kijken naar onze eigen praktijk, het schrijven van academische teksten. Zo ontstond het idee om de vorm van dit artikel te laten bepalen door de inhoud. Net als de filmmakers, streefden we naar een collectief werkdocument. Het resultaat is een metanarratief over het project PRISM, actuele thema's als dekolonisering, de samenwerking tussen An, Rosine, Eléonore en Natalie, filmmaken an sich en de vorm van het essay of interview. Talloze lagen die u, de lezer, er hopelijk toe kunnen brengen om deel te nemen aan de discussie en PRISM in het najaar van 2020 te gaan bekijken in de Beursschouwburg in Brussel.

1. LIESJE: Misschien zegt dit ook wel iets over onze vooroordelen en ideeën met betrekking tot het schrijven van dit soort wetenschappelijke bijdragen. Zijn dergelijke diepte-interviews minder relevant als uitdrukkingsmiddel voor Rosine en/of Eléonore? Is er misschien gewoon geen tijd voor door de (te) hoge werkdruk? Schieten wij toch tekort in onze communicatie en hadden we het anders moeten aanpakken? Een hele hoop vragen blijven aan het eind van dit werkstuk onopgelost. We kunnen er alleen maar over blijven nadenken.
STEFF: Het tot stand komen van dit artikel verliep niet zonder problemen. Vooral de communicatie met Rosine en Eléonore ging niet altijd vlot:

Bonjour Rosine et Eléonore!

Voici le résultat de notre interview avec An. Nous espérons que vous voulez réagit sur ce qu'on a tail.

Nhésitez pas de répondre a tous les questions que nous avons posé à An. N'hesitez pas de cliquer sur les liens que nous avons prévu qui d plus de contexte autour ce qu' on parle.

Icie et lä, nous avons ajouté des questions extras, spécifiquement pour vous. Nhésitez pas de dire que vous désapprouvez avec nous ou An dire pourquoi.

Si vous voulez, vous pouvez aussi ajouter des liens, des photos, du vidéos ou du son. Tout est possible I Même rayer des choses, ou rayer t Antw: PRISM: dernier appel

Bonjour steff,

Je suis vraiment désolée. Cette période est très chargée pour moi. Mais je vais tout faire pour vous envoyer mes réponses Eléonore

Dear Steffi,

Im really sorry for this silence but the last few weeks have been very intense for me with a lot of travel. I cidn't have the serenity to read the article

I will read it tonight and tomorrow I will come back to you very soon.

Im really sorry, but right now I'm very busy.

Thank you very much for understanding

Rosine

Ondanks verwoede pogingen om hun stemmen vanaf de start in dit essay/interview te betrekken door de tekst te laten vertalen naar het Frans en onze communicatie steevast drietalig te laten verlopen, sloegen de makers er door grote tijdsdruk slechts na enkele maanden in hun bedenkingen over de tekst te formuleren.

\section{STEFF: Exact. En de lezer van dit stuk vragen hetzelfde te} doen door deel te nemen aan het debat.

\section{? DE LEZER: ...}

STEFF: Hoe weinig prentjes er te vinden zijn van een vrouwelijke onbekende! Over 'decolonizing the (male) gaze' gesproken...

Wij bedanken An van. Dienderen, Rosine Mbakam, Eléonore Yameogo en Natalie Gielen voor de medewerking en Kristof van Baarle voor de begeleiding en de feedback. Grote dank gaat tevens uit naar het vertaalwerk van Liesje Baltussen, Laura Bogaerts, Eva Daans, Steff Nellis, Tom Uytterhoeven, Marloes Van Damme, Lise Van Rysseghem en Ilse Zurinckx. 